Ж. В. Колоїз

\title{
ЛЕКСИКО-СЕМАНТИЧНА ГРУПА «НАЗВИ ОДЯГУ» В РОМАНІ ВАСИЛЯ ШКЛЯРА «ЗАЛИШЕНЕЦЬ. ЧОРНИЙ ВОРОН»
}

Колоїз Ж. В. Лексико-семантична група «назви одягу» в романі Василя Шкляра «Залишенець. Чорний Ворон».

У статті досліджено структурно-семантичні особливості лексичних одиниць на позначення назв одягу, з-поміж яких виокремлено узагальнені (родові) та конкретні (видові); останні диференційовано залежно від функціонального призначення предметів, які вони позначають, на: а) назви головних уборів; б) назви власне одягу; в) назви взуття; з'ясовано прагматичний потенціал стилістично обмеженої лексики в конкретних мовленнєвих ситуаціях.

Ключові слова: лексико-семантична група, назви одягу, сема, стилістичні особливості, значення.

Колоиз Ж. В. Лексико-семантическая группа «названия одежды» в романе Василия Шкляра «Залишенець. Чорний Ворон».

В статье исследуются структурно-семантические особенности лексических единиц на обозначение названий одежды, среди которых выделяются обобщенные (родовые) и конкретные (видовые); последние дифференцируются в зависимости от функционального назначения обозначающих предметов на: а) названия головных уборов; б) названия собственно одежды; в) названия обуви; анализируется прагматический потенциал стилистически ограниченной лексики в конкретных речевых ситуациях.

Ключевые слова: лексико-семантическая группа, названия одежды, сема, стилистические особенности, значение.

Koloyiz Z. V. Lexical-semantic group "the names of clothes" is in the novel of Vasyl Shklyar "Zalyshenez. Chornyi Voron"

The article deals with the structural-semantic features of lexical units that mark the names of clothes. The generic and concrete categories of names are distinguished. Other names are differentiated in accordance 
with functional using of items that mean: a) the names of head-dresses; б) the names clothes; в) the names of shoes. The pragmatic potential of the stylistically limited vocabulary is found out in concrete speech situations.

Key words: lexical-semantic group, names of clothes, seme, stylistic features, meaning.

Серед тих специфічних проблем, які постають перед письменниками, представниками художньо-історичного жанру, неабиякої майстерності вимагає репрезентація культурно-побутового колориту епохи, відображення тих чи тих фрагментів об'єктивної дійсності. Авторові доводиться вибирати 3-поміж усього розмаїття такі засоби художнього розкриття історичного минулого, які сприяли б адекватному та рельєфному відтворенню особливостей зображуваної епохи. Це досягається передусім широким уведенням у канву художнього твору маркованої лексики, яка характеризує різні сторони суспільного, політичного та культурного життя народу, його побут та звичаї. Така лексика маніфестує класову структуру, соціальний стан, місце людини в суспільстві, суспільні взаємини тощо.

Для відтворення історичного минулого, маніфестації матеріальної і духовної культури народу досить активно «експлуатується» стилістично обмежена лексика. На сучасному етапі розвитку лінгвістики зростає наукове зацікавлення цією групою слів як у лінгвістичному, так і в історичному та в культурологічному планах. Для достовірного відображення історичних подій, створення живих, реалістичних образів, героїв минувшини письменникові недостатньо вивчити епоху, час, місце, умови, у яких розгортаються події. Необхідно знайти адекватні мовленнєві засоби, оскільки принцип історизму художнього відображення передбачає не тільки історично правильне розкриття ідеї, але і точне - у мовному вираженні - iі художнє втілення.

Новий роман Василя Шкляра «Залишенець. Чорний Ворон», над яким автор працював майже тринадцять років, скрупульозно вивчаючи документальні видання, зокрема й документи Галузевого державного архіву СБУ, отримуючи консультативну підтримку істориків, демонструє не лише одну з найдраматичніших сторінок нашої історії - повстанську боротьбу українців проти окупаційної влади у 1920-х роках, але й розмаїте лексикофразеологічне багатство мови, сло́ва, що репрезентують закодований у них дух історичної пам'яті, духовні цінності і символи нації.

У ньому знайшли відображення національні звичаї та традиції, які супроводжують людину протягом усього ії життя, пов'язані з появою на світ білий (А коли вона поклала вже розвереджену і нетерплячу дитину в ночви, то, купаючи ї̈ та скроплюючи свяченою водою, приказувала, як пописаному: «Будемо нашого хлопчика золотом-сріблом обсипати, від усякої напасті захищати. Будемо нашого козака святою водичкою мити, від бісииі боронити. Щоб лукава бісиия, юдина жінка, не підмінила дитину, поки будуть хрестини...» [9, с. 141]) і відходом у за́світи (...Боже духів $i$ всякої плоти, Ти смерть подолав $i$ диявола знищив, $i$ життя світові Твоєму дарував - Сам, Господи, упокой душу усопшого раба Твого Веремія 
на місці світлім, на місці квітучім, на місці спокійнім, звідки втекла болізнь, печаль $і$ зітхання; всяке прогрішення, вчинене ним словом або ділом, або помислом, як благий $і$ чоловіколюбецьь Бог, прости, бо немає чоловіка, щзо жив, а не згрішив би... Після короткої відправи труну опустили в яму, кинули зверху по жмені землі й засипали могилу <...> изього разу він завважив із подивом, щзо отецьь Олексій не тільки вкоротив молебень, але й не опечатав могилу... [9, с. 8-9].

Лексичний склад мови роману неоднорідний, передбачає велику кількість узуальних одиниць, що використовуються за різних умов i 3 неоднаковою метою, розгалуженими та неоднозначними стилістичними настановами. На тлі загальновживаної лексики яскраво вирізняються слова, які перебувають «поза основним фондом» [8, с. 216] і є стилістично маркованими. 3-поміж стилістично обмеженої лексики вирізняють розряд так званої побутової, або специфічно побутової [5, с. 145]. Це передусім назви будівель та їх частин (Так собі міркувала Ганнуся, стоячи біля причілка хати, аж поки вгледіла на вершечку акації чорного ворона [9, с. 24]; Ганнуся зійшла на приступку, яка так заскрипіла, щуо в неї похололо всередині [9, с. 47]; Такі балачки виводили мене з терпіння. Одного разу змучені, голодні, вимоклі на дощі, ми верталися до Лебединського лісу після невдалого нападу на гамазей торфової виробки біля Іванової Гаті й залізли в клуню перепочити та обсушитися [9, с. 69]; Вогонь перекинувся зі стріхи на повітку, на хлів, саж⿻, пасіку [9, с. 148]; За непу розхазяйнувався на всю губу - на його обійсті була й клуня, й повітка, $і$ загорода для худоби, і навіть копанка з карасями [9, с. 238]); назви хатнього начиння (Серед кімнати стояла широка дубова кухва, наповнена до половини брунатною купіллю, від якої сходив гарячий трав'янистий дух [9, с. 13]; 3 пітьми поволі почали проступати обриси звичайного льоху - $з$ діюками, кадобами, суліями, глечиками та іншим начинням, але те, щзо він побачив у кутку, штовхнуло його в самісіньке серие [9, с. 88]; Чикирда подав йому глечика з ряжанкою. Ходя взяв його за вушко, наче то був не трилітровий жсбанок, а звичайний кухлик, заглянув у нього, як сорока в кістку, нюхнув приплюснутим носом і почав хлебтати [9, с. 127]; Ворон добре знав його господаря, заможного удівцяя Онисима Лящза, який завжди приймав хлопців із лісу, не шкодував для них ні курей, ні яєцьь, ні сала, а мед зі своєї пасіки давав цілими цебрами [9, с. 146]); назви харчів та напоїв, їхніх вимірів (...итабс-капітан Чорновус (уже Чорновус) замовив для панн шампанське «Абрау», для панів офріцерів - карафу жнитнівки, попросив принести кав'яру, доброї смажсенини $і$ щуе всякої всячини [9, с. 33]; Виклала перед Вороном смажену курку, півпаляниці, жсуравель горілки, не забула й михайлика та сільничку [9, с. 158]; Хлопџуі принесли кавунів і доброї калганівки, вип 'ємо по чарупині [9, с. 176]; Жив він біля водяного млина над тим-таки Гнилим Тікичем, $і$ видно було, щзо це оселя мірошника, бо на сніданок ӥм подали все борочняне: вареники, галушки, гречаники, потапці. 
Охтанась і коням щедро всипав вівса, а для гостей до всього поставив на стіл карафу горілки [9, с. 213]; На столі, застеленому білою скатеркою, стояла карафка полинівки, пляшка червоного вина, у парі з паляницею лежав шммат доброї солонини, стояв ще горщик з печенею $i$ - звідки отець Олексій знав мої примхи? - глек непочатої ряюанки, затягнутої зверху апетитною брунатною кіркою [9, с. 224-225]); засобів пересування (Вони під’іхали чотириколісною бричкою до хати - це край села, біля Кривого Узвозу, де жили Веремієва мати та його молода дружсна Ганнуся [9, с. 22]; Марнота над марнотами, все намарне, - думав ворон, дивлячись услід бричці, яка віддалялася від Кривого Узвозу [9, с. 24]; Жаль було залишати в лісочку «пірса», проте їхати битими шляхами нам не годилося, а для лісу цей тарантас не підходив [9, с. 29]; Хтось, будучи, верхи поїде, а ми, кілька душ, із кучером покотимо на фаетоні, щзоб декому в носі закрутило [9, с. 56]; У них справді була припасена для такого діла ресорна бричка з відкидним верхом, на якій їздв покійний смілянський начміл Косовороткін [9, с. 56]; До полудня, коли мали розпочатися врочистості, набрякле хмарами небо вже погуркувало передгроззям, однак крізь браму цукроварні раз у раз проїздили брички, бідарки, підводи, верхівці й зупинялися на подвір'ї ближче до клубу, де їх зустрічав мідним ревом оркестр [9, с. 57]) тощо. Відображаючи здебільшого селянський побут, представлені лексеми демонструють виразні стилістичні особливості: на одних із них лежить відтінок розмовності (причілок - «бокова стіна будинка» [1, с. 958]; приступка - «східець» [1, с. 951]; чарупина «чарчина» [1, с. 1371 ] і т. ін. ), інші - отримали статус застарілих (гамазей «будівля для зберігання зерна, борошна» [1, с. 172]; карафа - «графин» [1, с. 416]; кав'яр - «ікра» [1, с. 409] і т. ін.). Подекуди проілюстровано здатність тієї чи тієї лексеми вступати в парадигматичні та синтагматичні відношення (пор. : чотириколісна бричка - «легкий візок для їзди, іноді 3 відкритим верхом» [1, с. 63]; тарантас - «чотириколісний візок на довгих розворах для далекої дороги» [1, с. 1231]; фаетон - «легкий чотириколісний екіпаж із відкритим верхом» [1, с. 1313] і т. ін.; сулія - «велика пляшка; бутель» [1, с. 1214]; карафа (жсравель) (горілки, жситнівки, калганівки, полинівки тощо) і т. ін.). Звертає на себе увагу те, що жоден зі словників не кодифікує значення звукового комплексу ж⿻уравель, представленого в контексті. Очевидно, ідеться про посудину, у якій зберігалася відповідна рідина. Перенесення відбулося за зовнішньою схожістю (пор.: ж⿻уравель «великий перелітний птах із довгими ногами, шиєю i прямим гострим дзьобом» $\mathrm{i}$ «пляшка 3 довгою тонкою шийкою»).

Проте, зауважимо, найсолідніше представлена в мові історичного роману лексико-семантична група «назви одягу». Такі лексеми репрезентують не лише побут повстанців, але й їхніх опонентів, демонструють відповідні лексико-семантичні особливості та потужний 
прагматичний потенціал, дослідження яких, власне, i стало метою нашої наукової розвідки.

Побутова лексика, зокрема й окресленої лексико-семантичної групи, вже неодноразово була предметом наукових студій лексикологів, діалектологів, істориків мови (Ф. Бабій, Л. Батюк, Г. Войтів, В. Горобець, Г. Гримашевич, П. Гриценко, К. Матейко, Г. Миронова, М. Никончук, I. Ощипко та ін.) [2; 3; 4]. I це цілком закономірно, адже, як справедливо наголошує Г. Войтів, «Історія номенів групи «одяг» викликає зацікавлення не тільки тому, що лексико-семантична система, а отже й окремі тематичні та семантичні об’єднання слів належать до найменш вивчених рівнів української мови. Інтерес до цього лексичного об'єднання визначається належністю назв одягу до лексики, тісно пов’язаної із одним 3 найрухливіших елементів матеріальної культури, що робить цю макрогрупу динамічною та стійкою і дуже цікавою з погляду дослідження кількісних та якісних змін, які можна простежити $\mathrm{i}$ в діахронії, i на синхронному зрізі» [2, с. 210].

У мові роману «Залишенець. Чорний Ворон» представлено як 1) узагальнені (родові) назви на позначення сукупності речей, якими покриває своє тіло людина (Серцее підказувало їй, щуо Веремій живий, інакше чого б ото замість небіжчика клали в труну лише його одяг? така омана була для неї незрозумілою і навіть зловісною [9, с. 24]), так і 2) конкретні (видові), що диференціюються передусім залежно від функціонального призначення предметів, які вони позначають. Наприклад: У Лисячій балці, недалечко від Мокрої Калигірки, його перестріли козаки Семена Гризла і привели до отамана - перевірити, хто такий. Кремезний, хоч і приземкуватий, Гризло здивував насамперед своїм убранням: синій ж⿻上пан, розшитий жовтими позументами, шаровари, козацька шапкабирка, з-під якої над чолом стриміло пасмо русявого чуба [9, с. 38] (пор.: убрання - «сукупність предметів, виробів із тканини, хутра, шкіри та ін., якими одягають, закривають тіло; одяг» [1, с. 1282] співвідноситься зі словами ж⿻пан, шаровари, шапка-бирка як загальне / часткове, родове / видове). Таке ж узагальнувальне значення отримують лексеми виряд, обмундирування, форма. Причому вони здебільшого мають при собі атрибутивні поширювачі, які вказують на належність, колір, призначення тощо. Наприклад: Ще не доӥхав до умовленого місия, як побачив трьох верхівців - Миколу Сильвестрова і двох чоловіків у червоноармійському виряді [9, с. 167] (пор.: виряд ᄂ виряджатися - «гарно, пишно вбиратися, причепурюватися або одягатися в незвичний одяг» [1, с. 109]); Гамалій щзе трохи почмихав, покрутив носом, а потім таки здався: добре, спиніть одного, але без крові - червоноармійське обмундирування відберіть, зброю, харчі, а людей не чіпайте [9, с. 202] (пор.: обмундирування «комплект форменого одягу» [1, с. 645]); - Я на тебе надіюся, Вовкулако. Зодягніть червоноармійські форми, прапора не бери, не дурій [9, с. 180] 
(пор.: форма - «спеціальний однаковий за кольором, кроєм та іншими ознаками одяг для осіб певної категорії» [1, с. 1328]). Проілюстровані контексти засвідчують активне використання атрибутивних супровідників для узагальнених назв одягу на зразок червоноармійський $(-a,-e)$. Однак значення атрибутивного поширювача іноді маніфестується й у вигляді тих чи тих кольороназв: Потім звів погляд на незнайомиів: один із них, зодягнутий, як продзагонівець, у брудно-зелену форму, дивився на Гупала з такою щиирою ціккавістю $і$ захопленням, що йому стало ніяково $[9$, с. 167]. У такому разі прикметник не лише конкретизує колір форми, але й увиразнює значення субстантивно-атрибутивного словосполучення загалом: брудно-зелений $\leftarrow$ брудний і зелений, де брудний - «сірувато-мутний; перен. який викликає моральну огиду, осуд; огидний, мерзенний» [1, с. 64].

1. Узагальнені назви одягу можна диференціювати за параметрами буденний / святковий. Для номінації буденного одягу використано узагальнені назви, що маніфестують виразні стилістичні особливості: Ворон та Вовкулака поскидали з себе намоклі лахи, Меланя занесла їх до печі сушитися [9, с. 239], де лахи - «розм. те саме, що лахмітmя; дуже старий, подертий одяг» [1, с. 482]. Найменування відповідного поняття репрезентується й описово, перифрастичним зворотом: Саме була неділя, базарний день, $і$ Чорновус, перевдягнувшись у жебрака, теж сходив у містечко, яке трохи знав [9, с. 39] (пор.: жжебрак - «людина, яка живе 3 милостині; старець» $[1$, с. 273] $\leftarrow$ дуже бідна людина $\leftarrow$ людина, одягнена y старий, подертий одяг). Щоправда, деякі з аналізованих назв у межах конкретної мовленнєвої ситуації отримують додаткові конотативні характеристики. Наприклад: Всі як один були перевдягнуті в будьонівське манаття, а Вовкулака їхав попереду ще й з червоним прапором [9, с. 52] (пор.: манаття - «зневажл. поганий одяг; лахміття» [1, с. 508]; утім, атрибутивний поширювач будьонівське свідчить про те, що, власне, акцентовано не на старому, подертому одязі, а на одязі людей, які загалом отримують негативну оцінку й автора, і літературних персонажів). Це саме спостерігаємо й у контексті Але я не червоний комісар. Я такий, як $і$ ти, пане отамане. Хіба тобі ніколи не доводилося перевдягатися в їхнє шммаття? [9, с. 259] (пор.: шмаття - «дрантя, лахміття» [1, с. 1401]; їхне шмаття, тобто шмаття (одяг) червоних комісарів). I в першому, і у другому разі йдеться про перевдягання повстанців задля реалізації поставленої мети у форму своїх непримиренних ворогів, окупаційної влади; стилістично нейтральні лексеми поступаються місцем тим, що вирізняються потужним прагматичним потенціалом.

Номінацію святкового одягу забезпечують спеціальні конкретизатори, як-от: святковий, вихідний, парадний і т. ін.: ...гостролиций сотник Бойко в парадному виряді австрійського офіцера з хрестами (теж австрійськими) на грудях і дерев'яним києм-булавою у правій руиі...[9, с. 122]; Була ще «святкова одіж⿻», але ми ї̈ берегли на особливий вихід [9, с. 361]; Потім 
вони по черзі підстригали одне одного, голилися, приміряли «вихідне» вбрання, тамуючи якесь дурне хвилювання... [9, с. 363] тощо.

Загальноприйнята класифікація конкретних (видових) назв одягу відсутня. Систематизація фактичного матеріалу здійснюється за різними параметрами і залежить певною мірою від того, який зміст вкладає той чи той науковець у витлумачення самого поняття «одяг». Звідси, відповідно, i виокремлення такої лексико-семантичної групи, як «назви одягу та взуття» [8, с. 214; див. також: 3; 4], що знайшло відображення й у мові роману. Наприклад: Окрім одягу та взуття, ми взяли тоді десяток револьверів, а рушниці сховали в Чуті, бо своїх мали вдосталь [9, с. 204]; Вчора в Мокрій Калигіриі більшовики розстріляли сорок наших людей та ще й повісили шістьох жидів, які шили нам одяганку і чоботи [9, с. 38].

3 огляду на те, що в сучасній українській літературній мові за лексемою одяг закріпилося основне значення - «сукупність предметів, виробів (із тканини, хутра, шкіри), якими покривають тіло» [1, с. 663], де під тілом розуміють «організм людини загалом 3 його зовнішніми i внутрішніми проявами» [1, с. 1249], логічно, вважаємо, розглядати назви взуття в межах лексико-семантичної групи «одяг». Тим паче, що іноді і сам контекст ілюструє широке витлумачення названого поняття: Мали ми про запас харчі, овес для коней, дещуо з одягу, запасся я, звісно, і грішми совєтськими, миколаївськими та польськими марками [9, с. 250]; Оспалий чоловік в одязі залізничника, тільки форменого кашкета бракувало, сказав, щзо все залишається так, як було домовлено [9, с. 210].

2. Конкретні (видові) назви одягу, якими послуговується В. Шкляр, слід диференціювати залежно від функціонального призначення предметів, які вони позначають, на такі типи: а) назви виробів, використовуваних для носіння на голові, або назви головних уборів; б) назви виробів, використовуваних для носіння на тулубі (корпусі), або назви власне одягу; в) назви виробів, використовуваних для носіння на нижніх кінцівках, або назви взуття. Лексеми всіх трьох тематичних розрядів зазвичай протиставляються за семами чоловічий / жіночий, не є однотипними щодо походження, структурно-граматичних та функціонально-стилістичних особливостей.

2. 1. Назви головних уборів, призначених для використання жінками, репрезентовані передусім звуковими комплексами хустина (хустка). Наприклад: Увечері після заходу сония Ганнуся низько запнулася хусткою, щуоб менше хто ї̈ впізнавав, як зустріне когось, нап 'яла стару свиту, взула розтоптані чоботи - бабуся та й годі...[9, с. 44] (пор.: хустка - «шматок тканини або трикотажний виріб переважно квадратний, який пов'язують на голову, шию, напинається на плечі»; пол. chusta, chustka [7, т. 4, с. 462]). Сема жіночий, відсутня в поданому витлумаченні, реалізується в межах контексту, як-от: Той прийшов сюди в жніночому вбранні, насунувши хустку на «сліпи», а тепер був у червоноармійському виряді, в кашкеті, 
під який заховав косичку [9, с. 290] (пор.: жіноче вбрання ↔ хустка); - Нам немає коли з вами розбалакувати, - зриваючи з голови хустку, сказав уже своїм голосом Вовкулака, і лиш тепер було видно, як йому не пасує баб'ячий одяг [9, с. 290] (про.: хустка ↔ баб'ячий одяг). Аналізована лексема супроводжується переважно атрибутивними поширювачами, що вказують на колір, якість, матеріал і т. ін. Наприклад: Вони вдвох випивали по чариі, до столу підтюпием дріботіла заклопотана Бениха, по-чудернацькому закутана в чорну хустину так, щуо стирчали рожеві вуха...[9, с. 39]; Паніматка - тиха та боязка жіночка в чорній, запнутій до самих очей хустині - напрочуд швидко й води загріла скупати дитину...[9, с. 256]. Чорний колір асоціюється 3 тяжким, безпросвітним, безрадісним життям (за народними звичаями, чорну хустину пов'язують тоді, коли перебувають у траурі). До того ж, як свідчить фактичний матеріал, жодного разу не йдеться про те, що хтось пов'язує хустину; здебільшого в неї закутуються, запинаються, закушкуються тощо, нібито намагаючись сховатися від усіх проблем тогочасної дійсності: Ta ось одного дня влетіла до них у хату не по літах метка Танасиха, заломила на грудях руки й, хитаючи з боку набік закушканою в три хустки головою, щзе з порога залементувала [9, с. 108]. У контекстах на зразок Ярка я ніс на грудях у перев'язаній через шию грубій хустці, а за спиною в мене ще був наплічник... [9, с. 271]; Квоччина сестра, плачучи, спорядила Вовкулаку $з$ дитиною в дорогу - замотала Ярка в чисту пелюшку, потім зав'язала у вовняну хустку так, щуо Вовкулака міг почепити дитину на шию і везти ї̈, як у колисиі [9, с. 200] представлено назви жіночих головних уборів, які за вимушених обставин змінюють своє функціональне призначення.

Назви головних уборів, призначених для використання чоловіками, представлені звуковими комплексами шапка, бриль, картуз, папаха, кашкет, безкозирка, будьонівка тощо. Найбільш нейтральним у стилістичному плані, очевидно, слід кваліфікувати слово шиака «чоловічий головний убір» [10, т. 4, с. 406] (пор.: «головний убір (переважно без полів, м'який, теплий)» [1, с. 1389]). Наприклад: У Василинки впала з голови шапка. Він підняв ї̈ і надів на Ходю [9, с. 362]. Значення, яке фіксує тлумачний словник, підтверджується низкою контекстів, де вказується на матеріал, з якого вона виготовлена: Cутяга, сидячи під дубом, сперся на стовбур і тихенько похропував. Голова йому впала на груди, бараняча шапка з ’̈хала низько на лоба [9, с. 316]; Мені щее нічого, я в чумарці та білій баранячій мапці (кінецьь довжелезної шаблі їе на коліщуатку), а Тіна в тоненькій рожевій сукні [9, с. 373] тощо. Для уточнення того чи того різновиду шапки використовуються прикладкові словосполучення, між компонентами яких встановлюються апозитивні відношення: ...козацька иапка-бирка, з-під якої над чолом стриміло пасмо русявого чуба [9, с. 38] (пор.: бирка - «овеча шкура; смушок» [1, с. 49], тобто мапка-бирка - «смушева шапка»); - Але на весну вони 
повернуться, і не сумлівайтеся, - знов увернув дідок $і$ хвацько підбив пужалном свою шапку-вушанку ще вище на лоба [9, с. 99] (пор.: вушанка - «зимова шапка з вухами, боковими частинами, що закривають вушну раковину» [1, с. 167]); Він приїхав до нас, як справжній козак, на доглянутому чалому коні, при зброї, у завеликій смушевій шапці-кубанці зі шкіряним верхом, яка часто з'їджала йому на очі [9, с. 310] (пор.: кубанка - «невисока смушева шапка 3 пласким верхом із тканини або шкіри» [1, с. 470]). Впадає в око те, що автор проводить чітку межу між назвами так званих повстанських і формених головних уборів: $Y$ mій коловерті вони загубили тільки Воронову смушеву шапку, за якою тепер він дуже шкодував, не так за самою шапкою, як за чорним иликом, на котрому було вишито два слова дівочою рукою: «Вертайсь росою» [9, с. 15]; На одній із них Ліда побачила свою бабусю-козачку - молоду, при шаблі, у смушевій папасі з довгим иликом. Поруч стояв бородатий чоловік у білій баранячій шапці, оперезаний портупеями [9, с. 380]; Знайшли, роздовбали вже мерзлу землю $і$ таки докопалися до труни, відкрили ї̈, та замість небіжчика знайшли тільки бриля, вишиванку й оту глумливу записку [9, с. 138]; У передку воза, запряженого парою мишастих коників, сидів дідок у шапці-вушанці, по боках, звісивши ноги з полудрабків і притримуючи на колінах рушниці, тряслися на вибоӥнах два міліціонери в иинелях $і$ картузах з червоними околишами [9, с. 98]; Iз чорного легковика вилізло троє - зодягнуті в рудо-зелене сукно, у високі важкі картузи, по боках теліпалися планшети [9, с. 286]; Ворон весело подивився на хом'ячка, нахилився $і$ враз насунув йому міліцейського кашкета на носа [9, с. 100]; Крім того, на мені була шинеля 3 комісарськими петлицями та формений кашкет із червоною пентаграмою на околиші, який трохи муляв стрижену голову [9, с. 249].

Лексеми шапка, nanaxa, активно використовувані для позначення назв головних уборів повстанців, доволі часто трапляється в супроводі найменувань відповідних елементів, деталей, зокрема звукового комплексу шлик («ісm. конусоподібний верх шапки (переважно 3 тканини), який звисав донизу» [1, с. 1400]), що, у свою чергу, як і назви самого головного убору, конкретизувався різними означальними компонентами (довгий, чорний, блакитний і т. ін.). Наприклад: - Вороне, ти жсивици? - почувся голос, а за тим голосом із вільшини виплив вершник на легкому, як тінь, коні, при шаблі, у короткому кожушку й сивій високій шапці з блакитним шликом [9, с. 19]; Він і не зоглядівся, як у повітрі майнула сива папаха 3 блакитним шликом, $і$ Ворон випростався у стременах майже на повен зріст, аби ї̈ упіймати [9, с. 21] (пор.: nanaxa - «висока хутряна чоловіча шапка, звичайно з суконним верхом» [1, с. 703]). Особливості крою nanaxu маніфестуються прикметниковими конкретизаторами на зразок високий, глибокий і т. ін. Наприклад: Що було насправді могутнім у Досі, то изе ї̈ довга розкішна коса, яку непросто було сховати навіть у глибокій 
nanaci, - Дося заправляла під шапку свій скарб по-факірському якимось особливим фасоном... [9, с. 19]; Це був Дядюра. Через високу папаху $і$ довгу бороду його голова здавалася більшою, ніж у коня [9, с. 236]. Назвою найпростішого головного убору, який характеризує принаймні одного 3 повстанців, є, безумовно, лексема бриль - «головний убір із широкими крисами» [1, с. 63] (пол. bryl < італ. ombrello - «парасолька, покриття над чимось» [7, т. 1, с. 177]). Іноді значення аналізованого слова витлумачується як «капелюх, здебільшого солом'яний» [6, т. 1, с. 257], що, власне, засвідчується й контекстуально: Надворі холодно, а він, біднесенький, босий i в солом'яному брилі [9, с. 65]; Він лежав на запряжених добрими кіньми санях - босий, простоволосий, у закривавленій вишиванці і споднях, тільки для більшої переконливості, щуо цуе таки Веремій, біля нього поклали щуе й солом'яного бриля, хоча надворі стояв мороз [9, с. 108].

Проілюстровані в наведених вище контекстах лексеми картуз, кашкет сприймаються як абсолютні синоніми (картуз - «те саме, що кашкет» [1, с. 419]; кашкет - «головний убір, шолом»; з пол. кaszkiet < pp. Casquette, що є зменшеним від casque - «шолом, каска» [6, т. 2, с. 411]). Їхню належність до форменого типу одягу засвідчують спеціальні поширювачі: кашкет (картуз) (мілічейський, формений, з червоними околишами, із червоною пентаграмою на околиші тощо). Подекуди та чи та сема актуалізується лише в межах контексту: Супроводжував нас червоний курсант, мовчазний, трохи розгублений нашим парадним виглядом хохол у рудому кашкеті з надламаним козирком [9, с. 122] (пор.: кашкет - «чоловічий головний убір із козирком» [1, с. 422]). I навпаки, конкретна мовленнєва ситуація може й, так би мовити, спростовувати необхідність певного семантичного елемента: Сльози навсправжки котилися по його щуоках $і$ не давали до пуття роздивитися на красиву тьотю в шкіряному кашкеті, таку поважну та пишну, наче вона була mут стариа над чоловіками...[9, с. 317] (у такому разі сема чоловічий втрачає свою актуальність). За умови ситуативного перенесення назви головного убору на назву особи (кашкет $\rightarrow$ особа, щзо його носить) відбувається семантична модифікація: Василинка сказав, щуо на них посунула чи не сотня «червоних кашкетів", та поки щуо їх удалося спинити [9, с. 345] (пор.: червоний кашкет Ł особа в кашкеті з червоним околишем). Червоні кашкети уособлюють представників радянської (окупаційної) влади й протиставляються білим безкозиркам царської армії: Розсунулася завіса, на сиені з'явився... солдат ще аж тої давньої-давньої цุарської армії, у білій безкозирці, білих итанах $і$ синьому мундирі 3 червоними відлогами [9, с. 59].

Стилістично значущою в історичному романі $є$ лексема будьонівка «вид військового головного убору», запозичена з російської мови, пов’язана 3 прізвищем Маршала Радянського Союзу Будьонного [6, т. 1, с. 280]. Негативно оцінне значення забезпечується, 3 одного боку, атрибутом 
рогатий (рогата будьонівка Ł рогата шапка $\leftarrow$ шапка з гострими кінциями, схожими на роги): ... згодом сюди прийдуть інші люди, вони гелготатимуть нетутешньою мовою, чужі, рогаті, себто в рогатих шапках-будьонівках [9, с. 9]; Момоти сторопіли ще дужче: отакої! козаки виявилися москалями, а москалі в рогатих будьонівках - козаками [9, с. 117]; з іншого, - атрибутом ганчір'яний (ганчір'яний $\leftarrow$ ганчірка «зневажл. про зношений, старий одяг» [1, с. 173]): Денис Гупало, який сховав свого піваршинного оселедия під ганчір'яний будьонівський шолом, навіть почав переконувати Загороднього, щзо тут щзось нечисте, щзо Завірюха заведе їх під дурного хату, однак Ларіон затявся: розтовкмач мені, щзо тут не так, і тоді я тебе послухаюся [9, с. 205]. Увиразнення відбувається й за рахунок уведення в мовленнєву ситуацію інформації про інші обов'язкові елементи відповідного головного убору: Отож головний черкаський «бебех» Яиа Гальперович сміливо, 3 вітерцем $i$ форсом вирушив у відкритому американському «пірсі»на Кременчук, $і$ так не дуже далеко й заӥхав, як за Худолї̈кою вигулькнуло йому назустріч кілька кіннотників у рогатих шапках-будьонівках з величезними ганчір'яними зірками на лобі [9, с. 25]. Величезні ганчір'яні зірки на лобі сприймаються повстанцями як тавро всього гріховного, того, що суперечить певним нормам, загальнолюдським цінностям. Напевне, у їхній уяві виникав образ рогатого чорта, посланця диявола, що, за біблійним свідченням, з'явиться незадовго до встановлення Царства Божого на землі i зобов'язуватиме людей поставити на лобі печать як свідоцтво свого визнання.

2. 2. Назви виробів, використовувані для носіння на тулубі (корпусі), або назви власне одягу, вирізняються з-поміж інших конкретних (родових) назв не тільки кількісно, але i якісно. У межах окресленого типу спостерігаються як інтегральні, так і диференційні ознаки, що уможливило подальшу систематизацію фактичного матеріалу. Усе розмаїття назв власне одягу, засвідчених у романі, об'єднується в такі підтипи: а) назви натільного одягу; б) назви поясного одягу; в) назви верхнього одягу.

3 огляду на семантику слова натільний до першого підтипу варто зараховувати назви, які позначають речі, зодягнені безпосередньо «на тіло». Серед них найпоширеніша лексема сорочка. У тексі роману вона використовується для номінації жіночої / чоловічої натільної білизни (пор.: у сучасній літературній мові і для номінації жіночого / чоловічого одягу, який надягають поверх білизни [1, с. 1162]). Наприклад: Сядь, поговоримо,сказав Ворон, трохи ніяковіючи від того, щуо, знявши сорочку, виставив напоказ свої шрами - ліворуч на грудях багріла така страшна згойна, ніби з нього виймали серие. Дося сіла на моріжок, напнувши на коліна сорочку, міцно обняла свої ноженята і якось боязко, ніби крадькома, подивилася йому в очі [9, с. 350]; ...коли вона, застібнувшись $і$ підкотивши рукави, дозволила Воронові подивитись на неї, він так само побачив усе, щуо ховалося під сорочкою...[9, с. 350]; Вони поклали Коляду на ліжко, Ворон 
розстебнув на ньому чумарку, задер закривавлену (хоч викрути) сорочку [9, с. 238]. Для конкретизації значення проілюстрованого слова, зокрема для актуалізації семантичних параметрів: а) натільна; б) білизна, автор десь-інде послуговується словосполученням спідня сорочка: Тиміш Компанієць по-московському тямив не дуже, тож подумав, щуо скоморох визвірився до нього, $і$, не зволікаючи, щее раз стрельнув трійчаткою - ї̈ олов'яний окрайок зацідив скоморохові в голову, той упав непритомний, навіть не охнувии, ікров - таки кров - дзюрком полилася йому на спідню сорочку [9, с. 203] (пор.: спідній - «який міститься внизу; нижній; який надягають під убрання (про білизну)» [1, с. 1171]).

Лексема сорочка подекуди отримує атрибутивний поширювач, що вказує чи то на колір (Тільки прийшла вона не в білій сорочці, а в коротенькому кожушку, хоч надворі стояло літо [9, с. 112]), чи то на довжину, коли йдеться про жіноче вбрання (Ocb i mym, y uзьому попівському домі, він щзоночі уявляв собі, як приходить до нього в довгій білій сорочці попівна, хоча ні разу ї̈ не бачив [9, с. 87]), чи то на матеріал, 3 якого виготовлено виріб (Він зняв із себе парусинову сорочку - вже невідомо якого кольору була та заношена сорочина...[9, с. 350] (пор.: парусиновий $\longleftarrow$ парусина - «груба, цупка льняна або напівльняна тканина» [1, с. 708]). Слово сорочина, репрезентоване в останньому контексті, відрізняється від слова сорочка стилістичним забарвленням, відтінком розмовності. Таким же стилістичним відтінком характеризується і лексема льоля, використовувана для позначення дитячої натільної білизни. Наприклад: Увечері Свдося викупала дитину, зодягла ї̈ в чистеньку льолю, яку сама пошила з мануфактурної байки, напоӥла козиним молоком, розведеним настоєм парила й меліси, і вклала у тверде дерев'яне ліжко, на якому спала й сама [9, с. 219].

До аналізованого підтипу належить також і слово вишиванка - «розм. вишита сорочка» [1, с. 120]. Українська вишита сорочка (здебільшого червоно-чорною мережкою) є для повстанця символом порядності, любові, святковості, окремішності, волі, щасливої долі, родової пам'яті і т. ін. Можливо, саме тому символічний образ вишиванки неодноразово присутній у романі: Він у брилі, в закривавленій вишиванці, шароварах $i$ босий [9, с. 66]; Він стояв у повен зріст, притулившись спиною до стіни конюшні, стояв роздягнутий, босий, простоволосий, лише закривавлена вишиванка та білі сподні прикривали його від холоду [9, с. 67]; Вона вільно спадала з-під бриля і зашморгувалася на шиї. Нижче, з-під розхристаної свити отамана, виглядала червоно-чорна мережка вишиванки [9, с. 340].

Окремий підтип становлять назви так званого поясного одягу, найменування чоловічого i жіночого вбрання, основним компонентом якого є пояс (пор.: поясний - «який носиться на поясі» [1, с. 915]). Таке вбрання прикриває нижню частину фігури, одягається безпосередньо на 
сорочку. У мові роману названий підтип репрезентований, з одного боку, лексемами, що номінують чоловіче вбрання, з іншого, - жіноче.

Домінантою 3-поміж назв чоловічого поясного одягу, очевидно, слід вважати слово штани, яке вирізняється й досить активним використанням. Наприклад: Сміялися $i$ з отаманової кобили Зірки, яка, зачувии весняну теплінь, втратила сором $i$ терлася об Солонькового жеребия, поки сідлом розірвала штани самому Солонькові [9, с. 16]; - Тагда держі, - вухатий дістав із кишені штанів цукерку. -Паабєдаєи! [9, с. 40]; - Купася халясо, - сказав він, натягуючи штани [9, с. 119]; - От икуродерська морда! - він гидливо витер руки об итани, чвиркнув через нижню губу $і$ вже хотів було ногою зіштовхнути труп у прірву, та враз передумав [9, с. 185]; Духом ми не впадемо, аби в декого итани не спали [9, с. 198]; Болбочан стояв босий, у штанах, у білій сорочцуі й усміхався до нас якоюсь несьогосвітньою посмішкою [9, с. 256]; Далі верховодила Маруся: вона сказала, щуоб я передав їй дитину, роззувся, зняв штани, узяв на плечі свою жінку $і$ брів нога в ногу за нею, Марусею, якщо не хочу nірнути до пояса [9, с. 276] тощо. Кожен із проілюстрованих контекстів маніфестує загальновідоме значення - «одяг (переважно чоловічий), який має дві довгі або короткі холоші й закриває нижню частину тулуба та ноги» [1, с. 1406]. Таке вбрання диференціюється залежно від функціонального призначення та виду, а самі найменування, об'єднуючись у синонімічний ряд, мають певні семантичні чи стилістичні відтінки. Так, скажімо, для номінації чоловічого одягу, який знаходиться під іншим одягом, використовується лексема підитаники - «чоловіча білизна; спідні» [1, с. 787], позначена відтінком розмовності: - Скидайте $i$ викручуйте підштаники, - сказав я. - Якщу вже йдете з нами, то соромитися нема чого [9, с. 119]. У свою чергу, слова підштаники, спідні, кальсони демонструють зразок абсолютних, тотожних за значенням синонімів (пор.: cnidнi - «підштаники, кальсони» [1, с. 1171]; кальсони - «те саме, що підитаники» [1, с. 411]; пол. kalesony запозичено з французької мови у значенні «підштаники» < іт. calzone - «штани» [6, т. 2, с. 356]). Наприклад: Вона дивилася нерухомими очима десь крізь Ворона, але він, скидаючи спідні, все-таки затулився однією рукою, $i$ коли нарешті заліз у кухву, відчув неабияку втіху [9, с. 13]; Я наказав карателям роззутися й роздягтися. Щулячись на шмалькому вітрі, вони роздяглися до споднів [9, с. 118]; - Виходь один на один, сучий тельбух! - гримнув найстарший брат Момот до Дерези, який у білих кальсонах, без люльки нічим не відрізнявся від решти перевертнів...[9, с. 118]; - Так єму, так єму!закричав кацап, схожий на скомороха - був у брудних кальсонах із розв'язаними поворозками, босий, а гороїжився так, ніби його було зверху [9, с. 203]. В останніх двох контекстах атрибутивні поширювачі вказують на колір виробу (білі кальсони) та деякі його деталі (кальсони 3 поворозками, де поворозка - «тасьма, шнурок» [1, с. 815]). Аналізований 
синонімічний ряд доповнюється лексемою білизна, що підтверджується контекстуально: Москалі вискакували з дверей та вікон у самій білизні, спросоння тікали навпрошки хто куди бачив, миготіли кальсонами через тини, перелази, городи, садки. Але ж якою доброю міменню були ті кальсони вночі! [9, с. 41]. У конкретних мовленнєвих ситуаціях ця лексема також отримує відповідні прикметникові конкретизатори, як-от: свіжа, лляна і т. ін.: Знайшов у сідельній сакві брусок пахучого трофейного мила, вимив чуба та бороду, викупався й зодягнув свіэну білизну [9, с. 146]; Я тільки дозволив хлопцям нашвидку перевзутися, щуоб менше лахів тягати в руках, та й собі підібрав нові кавалерійські чоботи й кілька пар лляної білизни [9, с. 121]. У такому разі важко зрозуміти, чи то автор ототожнює назви виробів (білизна = кальсони (сnідні, підштаники), чи то акцентує на одному зі складових елементів (білизна = кальсони (cnidнi, niдштаники) + спідня сорочка).

У межах репрезентованого синонімічного ряду знаходяться такі назви поясного чоловічого одягу, як шаровари та галіфе, що, на відміну від поданих вище, демонструють виразні семантичні особливості. Наприклад: Кремезний, хоч $i$ приземкуватий, Гризло здивував насамперед свойм убранням: синій жупан, розиитий жовтими позументами, маровари, козаџька шапка-бирка, з-під якої над чолом стриміло пасмо русявого чуба [9, с. 38]; ... козак Чикирда в шароварах, з ладанкою на ииї $і$ довжелезним оселедчем, якого він по-чудернацькому закрутив за вухо [9, с. 122] (пор.: шаровари - «широкі штани особливого крою, що їх переважно заправляють у халяви» [1, с. 1390]); Перед тим, як повкидати трупи «чопів» у провалля, вони потрусили їхні кишені, й Вовкулака налапав у Гоимана в галіфе дві золоті п'ятірки [9, с. 185]; На узліссі, де стояла його кобила Тася (ця красуня замінила Вовкулаці вбитого румака), він витяг із сідельної сакви галіфе $i$ віддав Прокіпковому швагерові [9, с. 194] (пор.: галіфе - «штани особливого крою, що обтягують литки й коліна та дуже розширюються на стегнах» [1, с. 171]). Перша лексема кількісно обмежена, трапляється при описі зовнішнього вигляду повстанців, осіб, що брали участь у визвольній боротьбі; інша, навпаки, використовується для характеристики людей протилежного табору, демонструє їхню причетність до відповідної професійної діяльності: таке вбрання здебільшого було частиною форменого одягу й подекуди мало чітко окреслені деталі: Особливо нам знадобився лантух синіх діагоналевих галіфе з червоними кантами (на жаль, до них не було кітелів), призначених для якогось міліщейського відділу, але мої хлопці вже так обносилися, щуо мілічіонери хай вибачають [9, с. 311].

Найменування жіночого поясного одягу представлені насамперед лексемами спідниця (спідничка) (пор.: спідниця - «жіночий одяг, що покриває фігуру від талії донизу» [1, с. 1171]). Наприклад: A спідничка $y$ неї теж була за останнім фасоном - довга, із синього ситияю, з иирокими 
шлейками [9, с. 94]; ...завів його в хату, де аж кишіло дітвори, яка, побачивши страшного дядька, відразу сипнула до маминоӥ спідниці [9, с. 193]. Атрибутивні поширювачі не лише вказують на розмір, колір, фасон, матеріал, особливості крою і т. ін. відповідного поясного одягу (i не тільки!), але й допомагають авторові продемонструвати зміну зовнішнього вигляду людини (наразі жінки) у зв’язку зі зміною іiі ідеологічних переконань, вималювати такий собі образ червоноармійки: Куземко був уже з Вовкулакою в отамана Гризла, а Ціля поміняла синю спідницю 3 широкими илейками на рудо-зелену, плисову блузку - на шкіряну жкакетку з мавзером при бочі, на голову пов'язала кіниями назад яскравочервону косинку [9, с. 95]; А нижче на Цілі були тільки рожеві панталони, такі короткі й благенькі, щуо Вовкулака ніколи таких не бачив, він навіть не підозрював, щзо таке можна носити [9, с. 103]. Останній контекст засвідчує ще одну лексему, що номінує жіночий поясний одяг (пор.: панталони - «заст. штани; жіноча білизна, яка покриває нижню частину тулуба від пояса звичайно до колін» [1, с. 702]). У попередній мовленнєвій ситуації, крім назви жіночого поясного одягу на зразок спідниця, проілюстровано найменування інших типів і підтипів, як-от: назви головних уборів (яскраво-червона косинка); назви верхнього одягу (плисова блузка, шкіряна жскетка).

Назви верхнього одягу займають важливе місце в лексикосемантичній групі «одяг» загалом та в підтипі «власне одяг» зокрема. Вони представлені найбільшою кількістю одиниць, що використовуються для позначення виробів, які одягають на корпус тіла здебільшого поверх натільного одягу. У такому разі при витлумаченні значення майже завжди актуалізується сема верхній, як-от, скажімо: жсупан - «старовинний верхній чоловічий одяг, оздоблений хутром і позументом, що був поширений серед заможного козацтва; засm. теплий верхній чоловічий суконний одяг» [1, с. 278]; куцина - «короткий верхній одяг» [1, с. 476]; пальто - «верхній одяг довгого крою, що надягається поверх плаття, костюма i т. ін.» [1, с. 700]; cypдym - «заст. чоловічий верхній двобортовий одяг 3 довгими полами, відкладним коміром і широкими лацканами» [1, с. 1225]; френч «військовий верхній одяг у талію, 3 чотирма накладними кишенями i хлястиком» [1, с. 1333] і т. ін. Наприклад: ...вони ж таки, видно з усього, збиралися грати й комедію, бо зодягнуті були, як лицедї, - хто в сурдуті з краваткою-бантом, хто в старорежимному офіцерському строї, хто у драній селянській куцині...[9, с. 60]; Після того, як чарупина пройшла по колу, досі мовчазного Голика-Залізняка потягло на балачку, і він, діставии з кишені фотокартку миловидого чоловіка у френчі червоного командира, простяг ї̈ Завірюсі [9, с. 176]; Повно чужих людей: чоловіки в сурдутах, жінки у довгих сукнях $[9$, с. 358] тощо.

У межах цього підтипу спостерігається чимало семантичних розрізнювальних ознак (буденний / святковий; формений / неформений; 
цивільний / військовий, довгий / короткий і т. ін.). Однак, вважаємо, цілком виправданою систематизацію матеріалу за двома основними різновидами: а) назви легкого одягу; б) назви теплого одягу. 3-поміж перших диференціюються лексеми для найменування як чоловічого, так i жіночого вбрання; інші - семами чоловічий / жіночий, як правило, не розрізняються. Хіба що в самому контексті може міститися вказівка на те, що певна назва використана для позначення теплого верхнього жіночого одягу: На ній було приталене сіре пальто зі стоячим комірцем із сивого смушку, такий же смушевий капелюшок...[9, с. 251] (пор. : смушок «хутро новонародженого ягняти; хутро вівці; шерсть» [6, т. 5, с. 332]).

Позначення легкого верхнього жіночого одягу здійснюється за допомогою таких лексем, як кофтина, блуза, сукня, жнакетка. Наприклад: Вона швидко налапала в темряві кофтину, натягла ї̈ через голову $i$, метнувшись десь до порога, принесла Торбину [9, с. 158] (пор.: кофтина - «коротенький (переважно нижче пояса) жіночий одяг» [1, с. 459]); Ціля була цікава жидівочка - тонка, як та голка, а груди наче позичила в кого чи підмостила дві дині, щуо аж розпирали рипсову блузку [9, с. 94] (пор.: блузка - «легкий короткий (до пояса) жіночий одяг; кофта» [1, с. 57]); Коли Ціля, задерши руки, солодко потяглася й жсакетка теж підскочила вгору...[9, с. 103] (пор.: жсакетка - «коротка жіноча одежа, яку носять поверх блузки або плаття» [1, с. 271]). Слова кофтина, блуза, жсакетка мають як інтегральні, так і диференційні семантичні ознаки: усі вони використовуються для номінації однакового за довжиною вбрання (актуалізується сема короткий); однак, на відміну від останнього слова, перші два можуть отримувати й певну семантичну конкретизацію, скажімо, блуза - «тоненька кофтина, виготовлена з ефірної тканини»: Збіса гарною була ия керівничя аматорського драмгуртка $i$ хористка гіпюрова блузка з рукавами-буфами робила ї̈ поставу ефірною, високий комірець відкривав недоторканно білу шию, а з-під напуску-німба короткої зачіски дивилися такі вельможні очі, щуо він мимоволі звернувся до неї на «ви» [9, с. 63] (пор.: гіпюрова блузка Ł блузка з гіпюру, де гіпюр - «сорт мережива з опуклим узором» [1, с. 183]). Зрідка для позначення поняття, що репрезентується звуковим комплексом блуза, використовуються слова, які номінують названий виріб через його деталі: ...одна ж прехороша панночка красувалася в рюшах, оборках й мереннивах... [9, с. 60].

Матеріальна форма вираження на зразок жсакетка отримує в романі контекстуальний поширювач у вигляді прикметника шкіряна: Ціля, тоненька, як голка, з розпущеним волоссям вийшла зі стодоли в шкіряній жсакетці, накинутій на голе тіло...[9, с. 103] (пор.: шкіряна жнакетка ᄂ жакетка, виготовлена зі икіри - «матеріалу, одержаного шляхом хімічної й механічної обробки шкури убитої тварини» [1, с. 1398]). Як свідчить фактичний матеріал, шкіряний одяг взагалі був досить популярним серед владних представниць. У результаті метонімічного перенесення (назва 
матеріалу, з якого виготовлено одяг $\rightarrow$ назва людини) виникає таке атрибутивне словосполучення, як шкіряна красуня. Наприклад: Дивлячись на них, шкіряна красуня зневажливо фиркнула $i$, ніби граючись, зробила те саме [6, с. 318].

Протиставлення за семами короткий / довгий легкий верхній жіночий одяг засвідчує лексема сукня: ...вона дістала Досі майже до колін, изе була простора сукня для Досі...[9, с. 350] (пор.: сукня - «жіночий одяг верхня частина якого, що відповідає кофті, становить єдине ціле 3 нижньою частиною, що відповідає спідниці; плаття» [1, с. 1214]).

Ряд номінативних одиниць на позначення легкого верхнього чоловічого одягу досить строкатий i представлений значною кількістю лексем, з-поміж яких вирізняються назви форменого одягу. Наприклад: Якийсь дикун з розхристаною на всі груди гімнастеркою - чи не їхній ватаг - під загальний регіт підійшов до курінного Чорновуса й потягся n'ятірнею до його лівого рукава, на якому золотів тризуб [9, с. 36] (пор.: гімнастерка - «військова формена сорочка з цупкої тканини з відкладним або стоячим коміром» [1, с. 182]); Я теж хотів було витерти тим папірием руки, але сотник Бойко, задзеленчавии хрестами, вихопив його в мене, склав учетверо й поклав до нагрудної кишені австрійського мундира [9, с. 127] (пор.: мундир - «парадний чи буденний одяг певної форми» [1, с. 544]; «формений одяг»; через посередництво запозичено з французької мови; фр. monture - «оправа; спорядження»; нім. Montur < від ісп. montura «кавалерійське спорядження» [6, т. 3, с. 534]); Туm, біля дверей, стояло двоє червоноармійців у білих кітелях, вони перевіряли документи, а перед деякими начальниками тільки витягувалися у струну й віддавали «честь» [9, с. 57] (пор.: кімель - «формена однобортна куртка зі стоячим коміром» [1, с. 431]; «куртка військової форми»; пол. kitel - «полотняний плащхалат» [6, т. 2, с. 451]). Слово кімель маніфестовано переважно в оточенні прикметникового компонента білий: 3-під напинала вискочило четверо запізнілих, але дуже суворих «начальників», один із них був бородатий, тому охоронеиьв у білому кімелі, щзо стояв на ганку, попросив пред'явити документи [9, с. 58]. Субстантивно-атрибутивне словосполучення білий кітель іноді розширює свою структуру за допомогою ще одного атрибутивного компонента зі значенням присвійності (Biн давно розхристав на собі білий міліцейський кітель (подарунок «бабусі Фундуклївки») і справді був не від того, щзоб освіжитись у ставочку після цілоденного «патрулювання доріг» [9, с. 355]), а десь-інде ілюструє й метонімічне перенесення: ...«білі кімельки», вхопивши ноги на плечі, дременули до своєї касарні, де вже також порядкувала всюдисущуа «чрезвичайка» [9, с. 59].

Назві куртки військової форми протиставляється найменування невійськового одягу, представлене в контексті лексемою піджак, супроводжуваною атрибутивним поширювачем цивільний. Наприклад: Я 
був уже в чорному сукняному пальті поверх цивільного піджака та в сірих штанях, заправлених у ті ж таки воснкомівські чоботи, які тепер кожен небідний чоловік міг купити чи виміняти на ярмарку [9, с. 270-271] (пор.: піджск - «верхня частина чоловічого костюма у вигляді куртки 3 рукавами й полами на застібці, звичайно з відкритим відкладним коміром» $[1$, c. 768]).

На окрему увагу заслуговують і інші назви чоловічого верхнього одягу, які містять інформацію чи то про спеціальне його призначення (для буденних / урочистих життєвих моментів), чи то про етнічну належність особи, яка його носить, чи то про особливості вбрання певного етносу: Це був добротний стьобаний халат чоловічого крою, Ходя «купив» його на станиії Цвіткове [9, с. 121] (пор.: халаm - «довгополий просторий верхній одяг (переважно без застібок)» [1, с. 1338]); I ось тепер, вибираючись на таку важливу й відповідальну зустріч із червоним командуванням, він вирішив зодягнути ией аристократичний балахон з бордового атласу [9, с. 122] (пор.: балахон - « просторий і довгий одяг, що надягається поверх усього для захисту від пилу; про широкий не підігнаний в талії одяг взагалі» [1, с. 35]); Один у френчі, другий у світленькому пильовику, а третій... третьою була жінка, тільки зодягнута по-чоловічому [9, с. 316] (пор.: пильовик - «плащ або легке пальто, що оберігає від пилу» [1, с. 758]); Скрипаль у чорному фраку з білим нагрудником $і$ довгими, схожими на пташиний хвіст фалдами, скидався на печальну сороку... [9, с. 34] (пор.: фрак - «чоловічий двобортовий одяг у талію, з вирізаними спереду полами та довгими фалдами ззаду, що його одягають в урочистих випадках, на офіційних учтах, для виступу в концертах» [1, с. 1332]); Назустріч їм виходив Бень у довгополому лапсердаку, горбатий, з рудою борідкою, проте милий $і$ чемний жид, який мав лісника Чорновуса за великого приятеля [9, с. 34]; За миколаївську золоту монету Аврум Віткуп, незважаючи на свій біблійний вік, навіть серед ночі піднімався з постелі, зодягав лапсердака, брав таку ж стару, як $і$ сам, пропахлу йодоформом валізку $i$ вирушав хоч на край свіmу [9, с. 239] (пор.: лапсердак «старовинний довгий верхній одяг польських і галицьких євреїв» [1, с. 480]; пол. lapserdak - «єврейський халат» [6, т. 3, с. 194]); На одній із галявин простелив на землі кавказьку бурку: прошу сідати, панове, в ногах правди немає... [9, с. 186] (пор.: бурка - «повстяний плащ або накидка 3 козячої вовни» [1, с. 67]) тощо.

Ряд номінативних одиниць на позначення теплого верхнього чоловічого одягу є значно меншим у кількісному плані, представлений лексемами бекеша, доха, кожух, пальто, чумарка, френч, иинеля і т. ін. Наприклад: $A$ за плечима у Чорного Ворона ще був карабін, кишеню чумарки відтягувала франиузька граната «кукурудза», $і$ він дивувався, як з усім ичим добром Мудей доніс його, непритомного, до Свдосі...[9, с. 15] (пор.: чумарка (чемерка) - «старовинний чоловічий верхній одяг, 
пошитий у талію з фалдами ззаду» [1, с. 1373]); ...щуе один гищель зі скляними очима, вбраний у шкіряну доху, підбиту, видно, псячим хутром, бо від нього нудотно тхнуло собачатиною [9, с. 139] (пор.: доха - «верхній одяг 3 хутряним верхом і 3 такою самою підкладкою» [1, c. 245]); - Aтставіть! - крикнув котрийсь із стариих, щуо був не в иинелі, а в білому коюусі [9, с. 68]; Він, иеей добрий дядечко, навіть заніс нам у клуню старого кожуха, «щцоб мама з дитятком не змерзли», а коли я, тречно подякувавши, сказав, щуо якби не він, то нам довелося б ночувати просто неба, дядечко простодушно підтакнув [9, с. 277] (пор.: иинеля - «верхній формений одяг особливого крою - зі складкою на спині та хлястиком, переважно для військових» [1, с. 1396]; кожух - «довга, не вкрита сукном шуба 3 великим коміром, пошита звичайно 3 овечої шкури хутром до середини» [1, с. 438]) тощо. Спостерігається диференціація за параметрами хутряний / нехутряний одяг. До розряду слів, у витлумаченні яких актуалізується сема хутряний, належать звукові комплекси доха і кожнх. Впадає в око й те, що останній доволі часто реалізує і вузькоспеціальне (технічне) значення: Спериу такий ріденький, щзо його краплі було видно лише на дулах рушниць та на кожухові «люйса», якого Дядюра примостив на тринозі поперед себе [9, с. 232]; Котрийсь із чонівців хотів було забрати кулемета, взяв його обіруч за кожсуха, та враз відсахнувся - йому здалося, щзо гайдамака живий [9, с. 245]; Я чув тільки, як треться об мої ребра кожсух його «люйса» [9, с. 346] (пор.: кожнух - «техн. оболонка, накриття, футляр і т. ін. для ізоляції або запобігання пошкодженню споруд, механізмів чи їх частин» [1, с. 438]). А лексема доха в окремих ситуаціях ілюструє переносне вживання: За ним посунула й псяча доха, лишивши по собі нудотний сопух, який переслідував Ганнусю навіть тоді, коли вона вийшла надвір ухопити свіжого повітря [9, с. 140]. Про належність того чи того слова до аналізованого підтипу десь-інколи може сигналізувати відповідний атрибутивний конкретизатор: Були цуе вже, видно, не раз катовані хлопиі, обдерті, худющі, зарослі, лище на одному був теплий френч, але такий брудний і заношений, щзо не розпізнати, якої він армї [9, с. 287].

Однак, зауважимо, найбільшою продуктивністю щодо вживання відзначається номінативна одиниця бекеша, у витлумаченні якої безпосередньо наявна необхідна інформація, - «чоловічий верхній теплий одяг старовинного крою з брижами в стані» [1, с. 47]. Наприклад: Вони під’ихали до галявинки, край якої лежав на простеленій бекеші Чорний Ворон, - його права рука була на перев'язі, поруч на траві лежсали карабін, револьвер, записник, стояв глечик із молоком [9, с. 174]; ...простора бекеша розіслалася на соломі, яка вже пахла не прілістю, а молочним колоссям, його руки заблукали в ї̈ одежі... [9, с. 150]; Завірюха привітався до нього, Ворон вайлувато підвівся, зачепив того глечика, $i$ біле молоко потекло на чорну бекешу... [9, с. 174]. Крім поширювачів, що вказують на форму, колір i т. ін. названого виробу (простора, чорна), подекуди використовуються й 
ті, які в конкретній ситуації отримують подвійну актуалізацію, як-от: Нарешті він зодягнув «вихідну» бекешу (ночі стояли іще холодні), в яку можна було загорнути цілий інститут иляхетних панянок, й осідлав коня [9, с. 146]; Простеливши на траві свою «вихідну» бекешу, Чорний Ворон лежав у холодку край невеличкої галявини, піджидав, поки хлопиі приведуть «дорогого гостя», $i$ намагався щзось мережити лівицею в потертому записничкові [9, с. 171]. 3 одного боку, актуалізується пряме значення слова вихідний («пов'язаний з виходом, появою кого-небудь десь»), з іншого, переосмислене («призначений для одягання, взування у святкові дні, в урочистих випадках або для виходу в гості і т. ін.» [1, с. 118]).

2. 3. Назви виробів, використовуваних для носіння на нижніх кінцівках, або назви взуття, репрезентовані в романі обмеженою кількістю лексем: для позначення жіночого взуття автор зазвичай послуговується звуковим комплексом черевички, чоловічого - чоботи. Причому перший iз відповідним значенням трапляється у творі двічі і лише в зменшенопестливій формі, що, напевне, дозволяє виокремлювати сему жіночий при витлумаченні значення цієї лексеми (пор.: черевики - «вид невисокого взуття переважно на шнурках чи гудзиках» [1, с. 1374]; інший - є досить активно використовуваним, засвідчує передусім граматичні особливості, зокрема однинну і множинну форми (пор.: чоботи - «рід взуття 3 досить високими халявами» [1, с. 1380]: Митрюха Гєрасімов не витримав, ударив мертвого чоботом, тоді вихопив у когось гвинтівку $i$ кольбою став гамселити в усміхнене, нестерпно красиве лицее [9, с. 18]; Жертви без жодного звуку падали ницьма з розколотими черепами, червона юшка бризкала Яиі на чоботи й галіфе [9, с. 28].

Лексема черевички разом із низкою інших назв одягу слугує для доповнення портретної характеристики: Туальденорова блузка з чорною краваткою, легенька ситцева спідниця, а нижче - тримайтеся, панове офіцеери! - рожеві фільдеперсові панчохи щуільно облягали ноженята в черевичках на високому підборі [9, с. 31] (пор.: туальденорова блузка ᄂ блузка з туальденору, де туальденор - «легка бавовняна тканина полотняного переплетення сірого кольору» [1, с. 1274]); На ній було приталене сіре пальто зі стоячим комірием із сивого смушку, такий же смушевий капелюшок, теплі модельні черевички $i$... чорні гарусові панчохи [9, с. 251]. Поєднання в межах одного контексту різних одиниць однієї лексико-семантичної групи сприяє вимальовуванню довершеного жіночого образу. В обох проілюстрованих ситуаціях наявна ще одна лексема, яку варто розглядати в межах аналізованого типу. Ідеться про звуковий комплекс панчоха - «виріб, який одягається на ноги за коліна» [7, т. 4, с. 19]. Вважають, що лексема запозичена з німецької мови через посередництво польської (пол. ponczocha < нім. Bundschuh - «в'язаний черевик; легке в'язане шнурами аж до колін селянське взуття», де Bund - «в'язка, моток» < binden - «в'язати, плести» i Schuh - «черевик, взуття» [6, т. 4, с. 280]. 
Конкретизаторами відповідної семантики виступають атрибутивні компоненти фільдеперсові, гарусові (пор.: рожсеві фільдеперсові панчохи ᄂ панчохи, виготовлені з фільдеперсу рожевого кольору, де фільдеперс «шовковиста пряжа, схожа на фільдекос, але спеціально оброблена, 3 якої виготовляють трикотажні вироби високої якості» [1, с. 1323]; чорні гарусові панчохи Ł панчохи, виготовлені з гарусу чорного кольору, де гарус «кручена (сукана) кольорова шерстяна пряжа» [1, с. 174]): - Hу ви і впрямь как не рускій! - сердито сказала Тіна і, майнувии в повітрі ніжками, обтягнутими чорними гарусовими панчохами, перекинула їх з крижівниці до воза [9, с. 262].

Лексеми чоботи (чобіт) використовуються здебільшого для номінації одного зі складових компонентів форменого одягу, у який вбрані переважно владні представники. Наприклад: Добре наобідані гості (бо де щее та святкова вечеря!) - червонопикі, масні, розпашілі, в парадних френчах, рипучих чоботях і портупеях, - лінькувато-весело козиряли один одному, ручкалися, щуось там собі погукували для годиться й повагом сходили на ганок [9, с. 57]; Четверо парламентарів: я зі своєю зарослою фізіономією $i$ гривою до плечей, у польовій блідо-зеленій формі та кавалерійських чоботях, халяви яких сягали вище колін; Ходя з косичкою $і$ в стьобаному бордовому хімоні... [9, с. 122]. У деяких контекстах міститься інформація про те, що звуковим комплексом чоботи позначено: а) не будь-яке взуття, а шкіряне (Біля Долбоносова сидів, високо закинувши ногу на ногу й помахуючи носаком хромового чобота, воєнком Красуиький, добродушний хитрий хохол, чепурний та наодеколонений, як $i$ всі потайні п'яниці [9, с. 57]; Розсупонив Гоимана в поясі, стяг із нього чоботи (нелегка изе робота - зняти з мертвого хромовики) $i$, взявши галіфе знизу, де звужуються холоші, так тріпонув, щзо Гоцман полетів у провалля, а галіфе зосталися в руках у Вовкулаки [9, с. 185] (пор.: хромовики $\leftarrow$ хромові чоботи $\leftarrow$ чоботи, виготовлені з хрому, де хром «м'яка, тонка шкіра, начинена солями цього металу» [1, с. 1354]); б) елементом цього взуття є халяви (високі, блискучі, гладенькі і т. ін.) (Вони одразу пішли до парадних дверей, поблискуючи гладенькими, ніби напрасованими, халявами [9, с. 286] (пор.: поблискуючи чобітьми $з$ гладенькими, ніби напрасованими, халявами); в) воно має підбори (Дося так крутнулася на підборах новеньких хромових чобіт, щзо з острогів посипались іскри [9, с. 19]); г) вдягається на спеціально намотану онучу (Це ж треба - утікав на коні, а от щзось замуляло йому в правому чоботі, виріиив перемотати онучу [9, с. 282]).

Повстанцям така розкіш, як добротні хромові чоботи, була недоступна: їхнє взуття радше скидалося на те, що позначалося словом икарбани: Ворон подивився на Гриия, на лахміття, в яке той був зодягнутий, $i$ подумав, щзо його обмотані ганчір'ям шкарбани не пролізуть у стремена. I тільки потім йому блиснув здогад, щзо так 
замотують чоботи не тільки для того, щуоб не погубити підошов. Так їх обкутують ганчір'ям швидще для того, щзоб не лищати слідів... [9, с. 335] (пор.: икарбани - «старе, топтане, рване взуття (чоботи, черевики і т. ін.)» [1, с. 1398]). Засвідчена мовленнєва ситуація, у якій лексема чоботи перебуває в оточенні атрибутивних компонентів, що безпосередньо вказують на спеціальне призначення. Наприклад: Ступаючи вслід за Марусею, я лиш тепер розгледів на ній рибальські гумові чоботи, халяви яких ховалися далеко під ї̈ спідницею [9, с. 275].

До аналізованого тематичного типу належать і лексеми пантофлі (пантофля): ...nантофлі в стременах - цее взагалі щзось незвичайне [9, с. 122]; Ми з гідністю злізли з коней, тільки Ходя скочив на землю з однією босою ногою, бо його права пантофля застрягла в стремені [9, с. 123]. Запозичена через польське i німецьке посередництво 3 французької мови [6, т. 4, с. 279]; іiі використано для позначення різновиду туфель, звичайно без закаблуків: а) м'яких ( $A$ om de саме, в якому контейнері Ходя роздобув стьобаного халата та м'які пантофлі, - не скажу [9, с. 121]) б) кімнатних (...кумедний вигляд мали його кімнатні пантофлі, які Ходя прикупив разом з халатом...[9, с. 122]). У конкретних мовленнєвих ситуаціях такі лексеми отримують додаткову виразність, сприяють створенню гумористичного ефекту. I не тільки. Наразі залишилося ще чимало цікавих у стилістичному плані моментів. Однак певні обмеження щодо обсягу статті унеможливлюють більш детальний опис систематизованої лексико-семантичної групи. Це вже предмет дослідження наступної наукової праці. А насамкінець узагальнимо: художній твір видатного письменника постачає нам багатющий фактичний матеріал, на основі якого можна простежити зміни в лексичному складі мови, досліджувати різні лексико-семантичні групи, що допомогли авторові правдиво відобразити історичні події, життя i побут двох ворогуючих таборів, віддзеркалити дух історичної пам'яті, духовні цінності і символи нації.

Проаналізована лексико-семантична група «назви одягу» представлена в історичному романі досить строкато. Вона передбачає узагальнені (родові) назви на позначення сукупності речей, якими покриває своє тіло людина, та конкретні (видові), що диференціюються передусім залежно від функціонального призначення предметів, які вони позначають, на: 1) назви виробів, використовуваних для носіння на голові, або назви головних уборів; 2) назви виробів, використовувані для носіння на тулубі, або назви власне одягу; 3) назви виробів, використовуваних для носіння на нижніх кінцівках, або назви взуття. Систематизація матеріалу здійснюється й у межах деяких підтипів, як-от, скажімо, назви власне одягу передбачають найменування таких різновидів вбрання: а) натільного; б) поясного; в) верхнього (легкого / теплого). 


\section{Література}

1. Великий тлумачний словник сучасної української мови / Укладач і головн. ред. В. Т. Бусел. - К. Ірпінь : Перун, 2001. - 1440 с.

2. Войтів Г. Українські назви одягу XIV-XVIII століть / Ганна Войтів // Записки Наукового товариства імені Тараса Шевченка : Праці Філологічної секції. - Т. 234 (CCXXXIV). - Львів, 1997. - С. 210-260.

3. Гримашевич Г. І. Назви одягу та взуття у контексті східнослов'янських мов (на матеріалі драми-феєрії Лесі Українки «Лісова пісня») / Г. І. Гримашевич // Режим доступу : http://www.ukrlit.vn.ua/article1/1548.html

4.Гримашевич Г. І. Структура полісемічних назв одягу в середньополіських говірках / Г. І. Гримашевич // Режим доступу : http://studentam.net.ua/content/view/8384

5. Дудик П. С. Стилістика української мови : [навчальний посібник] / П. С. Дудик. - К. : «Академія», 2005. - 368 с. - (Альма-матер).

6. Етимологічний словник української мови : у 7-и томах. - Т.1 / О. М. Мельничук (гол. ред.) - К. : Наукова думка, 1982. - 631 с.

Т.2 / О. М. Мельничук (гол. ред.).- К. : Наукова думка, 1985. - 570 с.

Т.3 / О. М. Мельничук (гол. ред.). - К. : Наукова думка, 1989. - 549 с.

Т.4 / уклад. : Р. В. Болдирєв та ін. - К. : Наукова думка, 2003. - 656 с.

Т.5 / уклад. : Р. В. Болдирєв та ін. - К. : Наукова думка, 2006. - 704 с.

7. Митрополит Іларіон. Етимологічно-семантичний словник української мови : у 4-х томах / за ред. Ю. Мулика-Луцика. - Т.1. - Вінніпег : «Волинь», 1979. - 365 с.

Т. 2 / за ред. Ю. Мулика-Луцика. - Вінніпег : «Волинь», 1982. - 400 с.

Т. 3 / за ред. Ю. Мулика-Луцика. - Вінніпег : «Волинь», 1988. - 416 с.

Т. 4 / за ред. Ю. Мулика-Луцика. - Вінніпег : «Волинь», 1995 - 557 с.

8. Сучасна українська літературна мова : Лексика і фразеологія / За заг. ред. І. К. Білодіда. - К. : Наукова думка, 1973. - 438 с.

9. Шкляр В. М. Залишенець. Чорний Ворон : [текст] / В. М. Шкляр. - Харків : «Клуб сімейного дозвілля», 2011. - 384 с.

10. Фасмер М. Этимологический словарь русского языка / М. Фасмер; [пер. с нем. О. Н. Трубачёв]. М. : Прогресс, 1973. - Т. 4. - 855 с.

Стаття надійшла до редакції 29.11.2011 р. 